\title{
The Effect of 16 Weeks of Resistance Training on the Fatigue Factor, Muscle Soreness, Oxidative Stress, and Myokine in Elite Weightlifters
}

\author{
Cheol-Woo Kim', Gun-Do Kim², Sung-Hwun Kang ${ }^{3}$, Chan-Hoo Park', Kwi-Baek Kim and Young-\| Kim* \\ ${ }^{1}$ Department of Sports \& Health Management, Youngsan University, Yangsan 626-790, Korea \\ ${ }^{2}$ Department of microbiology, Pukyong University, Busan 608-737, Korea \\ ${ }^{3}$ Department of Physical Education, Dong-A University, Busan 604714, Korea \\ ${ }^{4}$ Department of Physical Education, Busan University, Busan 609-735, Korea
}

Received December 2, 2011 / Revised December 22, 2011 /Accepted December 23, 2011

\begin{abstract}
The purpose of this study was to examine the effect of 16 weeks of resistance training on the fatigue factor, muscle soreness, oxidative stress, and myokine in elite weightlifters. A total of 10 subjects (six male, four female) participated in this study. The results were compared according to baseline, 8 weeks, and 16 weeks. Ammonia and Pi were increased through 16 weeks of resistance training, but this result was not significant. CK was significantly $(p<0.05)$ increased at 8 weeks and 16 weeks compared to baseline, while LDH was significantly $(p<0.05)$ increased at 8 weeks compared to baseline. The MDA of the oxidative stress factor was significantly $(p<0.05)$ increased at 8 weeks compared to baseline and 16 weeks, and TAS of the antioxidant factor was significantly $(p<0.05)$ increased at 8 weeks compared to baseline. The IL-15 of the myokine was significantly $(p<0.05)$ increased at baseline compared to 8 weeks and 16 weeks. In conclusion, 16 weeks of high-intensity resistance training may have a positive effect on peripheral fatigue factors, muscle soreness, oxidative stress, and myokine in elite weightlifters.
\end{abstract}

Key words : Basic fitness, fatigue, muscle soreness, oxidative stress, myokine

\section{서 론}

최근 한국 역도는 장미란 선수의 올림픽 금메달 획득으 로 인해 국민적 관심도 증가하고 이로 인해 많은 발전을 하 고 있다. 역도경기는 인상과 용상으로 나뉘며 이들의 경기 력 향상을 위해 다양한 훈련 프로그램이 운동생리학을 비롯 하여 운동역학, 스포츠 심리학 분야에서도 활발하게 연구되 고 있다.

역도경기의 특성상 체력요인 중 근력 및 근파워, 민첩성, 순발력, 평형성 등이 중요시되며 무엇보다도 슬관절이나 대퇴 근력이 중요시된다[5]. 경기력 향상 면에서 보면 영양 보충제 와 자세도 중요하지만 최근 들어 역도 수행 동작시 복부와 허리의 강화가 운동수행력을 증가시키고 부상방지에 긍정적 효과를 나타내는 것으로 보고[1]하고 있다.

국내 역도관련 운동 생리학적 연구를 살펴보면 특화된 트레 이닝[1,25]과 크레아틴 섭취[5] 등 역도선수의 근력 및 근 파워 향상에 초점이 맞춰 연구되어 왔다.

역도 경기의 특성은 단시간 내에 큰 파워를 생성할 수 있는 ATP-PCr 시스템을 사용하기 때문에 지속적인 고강도의 트레 이닝은 근육 피로 및 손상, 산화적 손상, 대사조절 cytokine 등에 작용하여 운동 수행력과 시합 결과에 큰 영향을 미칠

\section{*Corresponding author}

Tel : +82-55-380-9441, Fax : +82-55-380-9352

E-mail : kyi0234@ysu.ac.kr
것이라 사료된다.

기존의 청소년 엘리트 역도 선수들은 경기력 향상을 위 해 나이가 어림에도 불구하고 역도 종목의 특성상 많은 부 하의 피로와 저항을 견뎌야만 하는 운동 특성을 가지고 있 으며, 이는 엘리트 청소년 역도선수에 있어 필요악이라 할 수 있다. Liu 등[10]은 근력 트레이닝은 웨이트 트레이닝 선 수나 파워스포츠 선수의 근육의 힘과 신체구성을 유지하기 에 중요하지만 적절치 못한 트레이닝일 경우, 세포의 손상 과 산화적(oxidative stress) 스트레스가 증가하게 되며 이러 한 산화적 손상은 골격근의 피로와 호흡근, 운동 수행력, 회 복에 손상을 미치게 된다[23]는 것을 볼 때, 피로와 근 손상, 산화적 손상, myokine의 지표들은 현재 중학교 역도 선수들 의 트레이닝 프로그램을 구성하는데 중요하게 고려되어야 할 지표라 생각된다.

현재 $\mathrm{k}$ 지역 중학교 지도자들은 경기력 향상을 위해 전형적 인 훈련방법으로 시합대비 16주 근력 트레이닝 프로그램[14] 을 기초로 실시하며 그 밖의 훈련(코어 및 TRX 훈련 등)은 필요에 의해 추가로 선택하여 실시하는 형태를 취하고 있다. 하지만 현재 실시해고 있는 고강도의 저항성 트레이닝이 실제 적으로 성장기 중학교 역도 엘리트 선수의 체력 및 경기력 향상, 생리적 적응에 효과적인지에 대한 연구는 국내·외적으 로 부족한 실정이다. 최근 지방조직에서 분비되는 cytokine보 다 운동하는 근육에서 생성 및 방출되는 cytokines (myokines) 이 혈중에서 더 많은 비율(약 65 90\%)을 차지 하며 오늘날 
IL-6 및 IL-8, IL-15, Fibroblast growth factor 21, brain-derived neurophic factor (BDNF)는 myokines으로 정의[2]되고 있다. 이러한 이유로 역도선수에 있어 피로물질과 산화적 스트레스, IL-6와 IL-8, IL-15가 고강도 트레이닝으로 인해 어떻게 변화하 고 적응되는지 분석은 의미 있다 사료되며 특히 최근 들어 운동선수에 있어 IL-6와 IL-8, IL-15는 myokine으로 분류되는 바, 이 물질에 대한 추가적 분석이 요구된다.

따라서 본 연구의 목적은 중학교 엘리트 역도선수(남 6, 여 4) 총 10 명을 대상으로 16 주 근력 트레이닝을 동반한 TRX 및 코어 트레이닝이 기초 체력 및 피로, 근 손상, 산화적 손상, myokine 지표에 미치는 영향을 파악하여 성장기 중학교 엘리 트 역도선수를 위한 효과적인 근력 트레이닝 프로그램 구성에 기초자료로 제시되는 것이다.

\section{재료 및 방법}

\section{연구대상}

본 연구는 K지역 중학교 역도 엘리트 선수 10 명을 대상으로 하였다. 피험자 선정은 지도자 및 코치가 추천하였으며 과거 로부터 현재까지 가족력이나 질환이 없으며 이전 역도 선수 경험이 1년 이하 이거나 처음으로 운동을 시작하는 대상자로 서 남자 6 명과 여자 4 명, 총 10 명을 선출하였다. 이들은 한 신체적 특성은 Table 1에 나타나 있다.

\section{실험 절차}

\section{신장 및 체중, 체지방 측정}

신장 및 체중 측정은 신장 및 체중 측정계(JENIX, model DS-102)로 측정하였고 체지방 측정은 체지방 측정계(자동 무 인건강지원시스템, $\left.\mathrm{O}_{2} \mathrm{Run}\right)$ 을 통하여 측정하였다.

\section{안정시 심박수와 안정시 혈압 측정}

안정시 심박수와 혈압은 편안이 앉은 자세로 측정 30 분 안 정을 취한 후 자동혈압계(COLIN, model BP-203 RVII)로 측정 되었다.
16 주 근력 운동프로그램 및 Core, TRX 운동프로그램

근력 트레이닝 프로그램은 역도단계별 기술 강화 훈련서 [14]를 기준으로 16 주, 주 6회로 구성하여 1-2주는 준비기 및 기초전문 훈련을 실시하였고 3-8주는 전문훈련기, 9-13주는 경 기준비기(기록향상), 14-16주는 시합기로 나누어 구성하였다 (Table 2). 또한 Core 트레이닝의 경우 9개 동작으로 구성되며 그 중, 1. Reverse Crunch와 2. Back Extension은 3set×15rep, 3. Banana는 40 rep, 4. Bridge-Ups 과 5. Crunch, 6. Dolphin pose는 $3 \mathrm{set} \times 10 \mathrm{rep}, 7$. Hip Flexor는 좌우 $15 \mathrm{set} / 15 \mathrm{sec}, 8$. Modified side plank는 좌우 $30 \mathrm{set} / 30 \mathrm{sec}, 9$. Superman은 $60 \mathrm{sec}$ 로 구성되었다. TRX 트레이닝의 경우, 8가지 동작으로 1. Chest Press, 2. Suspended Crunch, 3. Single Leg Squat, 4. Standing Back Extension으로 $2 \operatorname{set} \times 8$ rep로 구성되며 5 . Suspended Oblique Crunch는 좌우 $6 \mathrm{sec}, 6$. Body Saw는 2 set×8 rep로 구성되었다(Table 3).

\section{혈액성분 분석}

피험자들은 혈액 체혈 전으로부터 약 9시간 정도 공복상태를 유지하도록 한 후, 혈액은 일회용 주사기를 사용하여 상완정맥

Table 2. 16 week resistance training program

\begin{tabular}{cl}
\hline Exercise duration & Training object \\
\hline \multirow{3}{*}{$1 \sim 2$ weeks } & 1 week: \\
& Condition check \& prepare mode \\
& 2 week: \\
& Basic specialty training \\
\hline \multirow{2}{*}{$3 \sim 8$ weeks } & 6 week: \\
& -specialty training \\
\hline & 6 week: \\
& Game prepare mode \\
& -Specific strength maintain \\
& \& build up \\
& -Best condition maintain \\
\hline & 2 week: \\
& -Game season \\
& -Best condition maintain \\
\hline
\end{tabular}

Table 1. Comparison of characteristics baseline and 16weeks resistance exercise training

\begin{tabular}{|c|c|c|c|c|}
\hline \multirow{2}{*}{ Variable } & \multicolumn{2}{|c|}{ Elite juvenile weight lifters $(n=10)$} & \multirow{2}{*}{ T-score } & \multirow{2}{*}{ P-value } \\
\hline & Baseline & 16 weeks & & \\
\hline Age (yr) & \multicolumn{2}{|c|}{$13.8 \pm 1.39$} & - & - \\
\hline Height (cm) & \multicolumn{2}{|c|}{$163.16 \pm 6.52$} & - & - \\
\hline Weight $(\mathrm{Kg})$ & $66.54 \pm 17.23$ & $67.76 \pm 13.88$ & -.494 & .633 \\
\hline Fat $(\%)$ & $22.87 \pm 8.51$ & $23.58 \pm 8.19$ & -1.187 & .266 \\
\hline Rest HR (beats/min) & $82.50 \pm 14.57$ & $75.55 \pm 7.69$ & 2.161 & .059 \\
\hline Rest SBP (mmHg) & $119.5 \pm 22.73$ & $123.7 \pm 9.28$ & -.645 & .535 \\
\hline Rest DBP (mmHg) & $63.00 \pm 7.57$ & $66.55 \pm 5.43$ & -1.639 & .136 \\
\hline
\end{tabular}

Values are mean \pm S.D.

HR: heart rate, SBP: systolic blood pressure, DBP: diastolic blood pressure 
Table 3. 16 week TRX and Core training program

\begin{tabular}{lllc}
\hline \multicolumn{2}{c}{ TRX strength training } & \multicolumn{2}{c}{ Core strength training } \\
\hline \multicolumn{1}{c}{ Exercise mode } & Exercise intensity (set/rep or sec) & \multicolumn{1}{c}{ Exercise mode } & Exercise intensity (set/rep or sec) \\
\hline 1. Chest Press & $2 \mathrm{set} \times 8 \mathrm{rep}$ & 1. Reverse Crunch & $3 \mathrm{set} \times 15 \mathrm{rep}$ \\
2. Suspended Crunch & $2 \mathrm{set} \times 8 \mathrm{rep}$ & 2. Back Extention & $3 \mathrm{set} \times 15 \mathrm{rep}$ \\
3. Single Leg Squat & $2 \mathrm{set} \times 8 \mathrm{rep}$ & 3. Banana & $3 \mathrm{set} \times 40 \mathrm{rep}$ \\
4. Standing Back Extension & $2 \mathrm{set} \times 8 \mathrm{rep}$ & 4. Bridge-Ups & $3 \mathrm{set} \times 10 \mathrm{rep}$ \\
5. Suspended Oblique Crunch & R6/L6 sec & 5. Crunch & $3 \mathrm{set} \times 10 \mathrm{rep}$ \\
6. Body Saw & $2 \mathrm{set} \times 8 \mathrm{rep}$ & 6. Dolphin pose & $3 \mathrm{set} \times 10 \mathrm{rep}$ \\
& & 7. Hip Flexor & R15/L15 sec \\
& & 8. Modified side plank & R30/L30 sec \\
\hline
\end{tabular}

(anttcubital vein)에서 채혈하였다. 무기인산(phosphate)은 화 학적 측정법(피스케, 사바로우법)을 사용하였고 Hitachi (社)의 모델 7600 사용하였고 암모니아(ammonia)는 Glutamate dehydrogenase를 이용한 효소법으로 COBAS Integra 800을 사 용하여 측정하였다. CPK (Creatine Phosphokinase)는 UV Kinetic (JSCC 표준화 반응) 측정방법을 사용하였고 $\mathrm{LDH}$ (lactate dehydrogenase)의 경우 효소법을 통해 Hitachi 7600 으로 분석하였다. MDA는 $10.3 \mathrm{mM} \mathrm{N}$-methyl-2-phenylindole $650 \mu \mathrm{l}$ 를 희석하고, 샘플 $200 \mu \mathrm{l}$ 를 첨가하여 3 4초간 vortex를 하였다. 이후 $36 \% \mathrm{HCL}$ 용액 $150 \mu \mathrm{l}$ 를 첨가하고 잘 혼합한 후 60 분 동안 $45^{\circ} \mathrm{C}$ 에 배양한 뒤 Diode Array spectrophotometer 를 이용하여 $585 \mathrm{~nm}$ 에서 흡광도를 측정하였으며 TAS (Total Antioxidant Status)는 Colorimetry 측정방법을 사용하여 Hitachi 7600을 사용하여 측정하였다.

IL-6, IL-8, IL-15은 Human serum cytokine kit를 이용하 여 Bio-Plex pro magnetic cytokine assay를 이용하여 각각 분석하였다. 모든 component는 $4{ }^{\circ} \mathrm{C}$ 에 보관하여 실험시 Standard, sample, cytokine magnetic beads를 각각 dilution하고 dilution 한 standard와 sample을 각 well에 $50 \mu \mathrm{l}$ 씩 분주한 다음 30 분간 shaker incubation 하고 3 번의 washing을 실시하였다. 그러 다음 detection antibody를 준 비하여 각 well에 $50 \mu \mathrm{l}$ 씩 분주한 다음 30 분간 shaker incubation 이후, 3 번 washing 하였다. 그 다음 assay buffer를 이용하여 streptavidin-PE를 준비하여 각 well에 $50 \mu \mathrm{l}$ 씩 분 주한 다음 다시 10 분간 shaker incubation 한 다음 3 번 washing하였다. 마지막으로 $125 \mu \mathrm{l}$ 의 assay buffer를 각 well에 분주하고 30초간 shaking 한 후 Bio-rad 사 Bio-Plex computer Manager를 이용하여 분석하였다.

\section{통계 분석}

본 실험의 결과는 SPSS 통계 package (ver 12.0)를 이용하여 각각의 실험에 따른 요인들의 변화를 알아보기 위해 기술통계 량(평균과 표준편차)을 산출하였다. 16주 근력 및 코어, TRX 트레이닝 적용 전·후에 따른 신체적 특성과 기초체력의 유의
한 차이를 알아보기 위해 대응분석(t-test)을 실시하였고, 트레 이닝 전(0주)와 트레이닝 중(8주), 트레이닝 종료(16주)시의 피 로, 근 손상, 산화적 손상, myokine의 차이를 분석하기 위해 일원변량분석(One-way ANOVA)을 실시하였다. 사후검증은 Turkey로 유의수준은 0.05 에서 검증하였다.

\section{결 과}

\section{신체적 특성}

16 트레이닝 전, 후의 신체적 특성은 Table 1에서 나타냈다. 나이와 신장은 두 집단에서 유의한 차이가 나지 않았다. 체중 은 트레이닝 전 $(66.54 \pm 17.23 \mathrm{~kg})$ 에 비해 트레이닝 후 $(67.76 \pm$ $13.88 \mathrm{~kg}$ ) 증가함을 나타냈지만 통계적으로 유의한 차이는 나

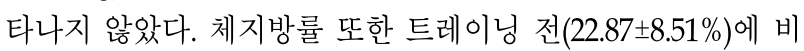
해 트레이닝 후 $(23.58 \pm 8.19 \%)$ 로 증가함을 나타냈지만 통계적 으로 유의한 차이는 나타나지 않았다.

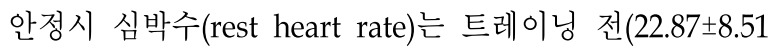
beats $/ \mathrm{min})$ 에 비해 트레이닝 후 $(23.58 \pm 8.19$ beats $/ \mathrm{min})$ 로 감소함을 나타냈지만 통계적으로 유의한 차이는 나타나지 않았다.

안정시 수축기혈압(rest systolic blood pressure)은 트레이 닝 전 $(119.5 \pm 22.73 \mathrm{mmHg})$ 에 비해 트레이닝 후 $(123.7 \pm 9.28$ $\mathrm{mmHg}$ )로 증가함을 나타냈지만 통계적으로 유의한 차이는 나타나지 않았다. 또한 이완기 혈압(rest diastolic blood pressure)도 트레이닝 전 $(63.00 \pm 7.57 \mathrm{mmHg})$ 에 비해 트레이닝 후 $(66.55 \pm 5.43 \mathrm{mmHg})$ 로 증가함을 나타냈지만 통계적으로 유의 한 차이는 나타나지 않았다.

\section{6주 트레이닝 전과 중, 종료 시 피로물질}

16 주 트레이닝 전, 중(8주), 종료(16주)의 피로 요인은 Fig. 1 에서 나타냈다.

암모니아 $\left(\mathrm{NH}_{3}\right)$ 는 트레이닝 전 $(50.9 \pm 36.3 \mathrm{ug} / \mathrm{dl})$ 에 비해 트 레이닝 8 주 $(53.7 \pm 13.4 \mathrm{ug} / \mathrm{dl})$ 와 트레이닝 종료 16주(54.2 \pm 13.1 $\mathrm{ug} / \mathrm{dl}$ 로 점차 증가함을 나타냈으나 통계적으로 유의한 차이 


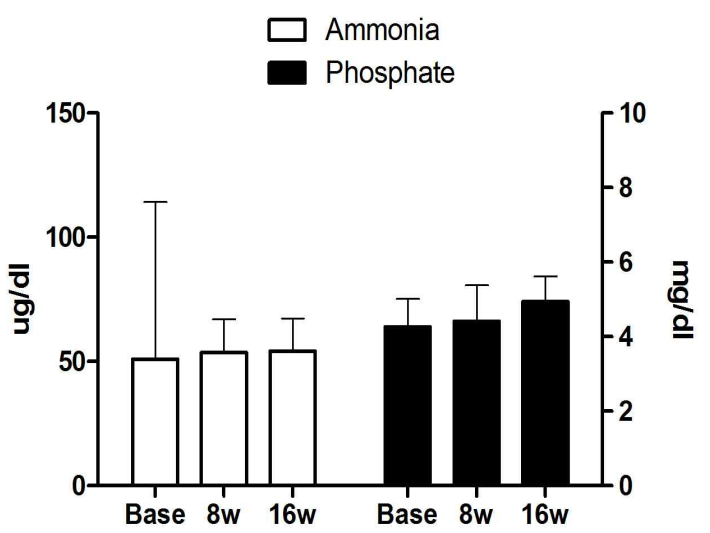

Fig. 1. The change of Ammonia and pi during 16 weeks.

는 나타나지 않았다.

인산 $(\mathrm{Pi})$ 는 트레이닝 전 $(4.26 \pm 0.75 \mathrm{mg} / \mathrm{dl})$ 에 비해 트레이닝 8 주 $(4.41 \pm 0.97 \mathrm{mg} / \mathrm{dl})$ 와 트레이닝 종료 16 주 $(4.95 \pm 0.67 \mathrm{mg} / \mathrm{dl})$ 로 점차 증가함을 나타냈으나 통계적으로 유의한 차이는 나타 나지 않았다.

\section{6주 트레이닝 전과 중, 종료 시 근 손상 물질}

16주 트레이닝 전, 후의 피로 요인은 Fig. 2에서 나타냈다.

혈중 $\mathrm{CPK}$ 는 트레이닝 전(147.7 $\pm 54.7 \mathrm{I} \mathrm{U} / \mathrm{l})$ 에 비해 트레이닝

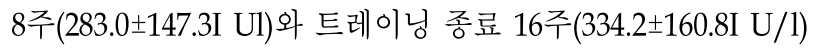
에 통계적으로 유의하게 $(p<0.05)$ 증가함을 나타냈다.

혈중 $\mathrm{LDH}$ 는 트레이닝 전(197.2 $223.4 \mathrm{I} \mathrm{U} / \mathrm{l})$ 에 비해 트레이 닝 8 주(281.1 $\pm 67.4 \mathrm{I} \mathrm{U} / \mathrm{l})$ 에 통계적으로 유의하게 $(p<0.05)$ 증가 함을 나타냈고 트레이닝 종료 16주(236.0 $18.6 \mathrm{I} \mathrm{U/1)에는} \mathrm{트레}$ 이닝 전, 수준으로 감소함을 나타냈다.

\section{6주 트레이닝 전과 중, 종료 시 산화적 손상 물질}

16주 트레이닝 전, 후의 피로 요인은 Fig. 3에서 나타냈다.

혈중 $\mathrm{MDA}$ 는 트레이닝 전 $(1.95 \pm 0.22 \mathrm{nmol} / \mathrm{ml})$ 에 비해 트 레이닝 8 주 $(2.84 \pm 0.27 \mathrm{nmol} / \mathrm{ml})$ 와 트레이닝 종료 16 주 $(1.74 \pm$

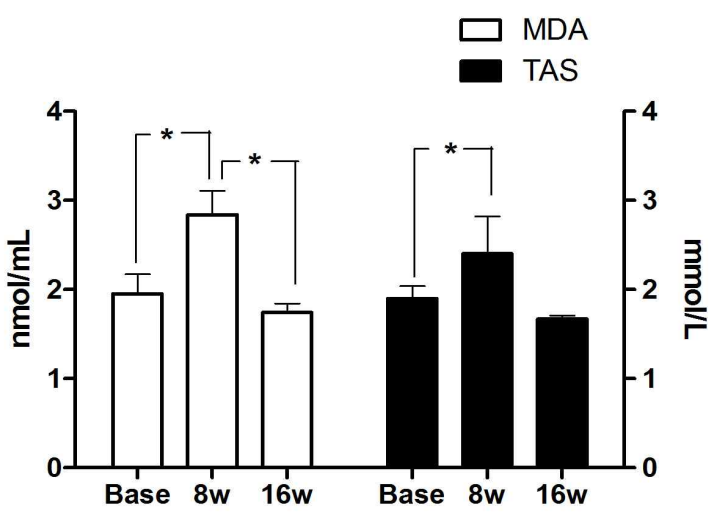

Fig. 3. The change of MDA and TAS during 16 weeks.

$0.10 \mathrm{nmol} / \mathrm{ml})$ 에 통계적으로 유의하게 $(p<0.05)$ 증가함을 나타 냈다.

혈중 TAS는 트레이닝 전 $(1.9 \pm 0.14 \mathrm{mmol} / \mathrm{l})$ 에 비해 트레이 닝 8 주 $(2.4 \pm 0.42 \mathrm{mmol} / \mathrm{l})$ 에 통계적으로 유의하게 $(p<0.05)$ 증 가함을 나타냈고 트레이닝 종료 16 주 $(1.67 \pm 0.04 \mathrm{mmol} / \mathrm{l})$ 에는 트레이닝 전 수준으로 감소함을 나타냈다.

\section{6주 트레이닝 전과 중, 종료 시 myokine}

16주 트레이닝 전, 후의 피로 요인은 Fig. 4에서 나타냈다.

혈중 IL-6는 트레이닝 전 $(12.6 \pm 3.69 \mathrm{pg} / \mathrm{ml})$ 에 비해 트레이 닝 8 주 $(15.7 \pm 5.61 \mathrm{pg} / \mathrm{ml})$ 와 트레이닝 종료 16주(17.5 \pm 7.23 $\mathrm{pg} / \mathrm{ml})$ 에 증가함을 나타냈지만 통계적으로 유의한 차이는 나 타나지 않았다.

혈중 IL-8는 트레이닝 전 $(19.6 \pm 5.22 \mathrm{pg} / \mathrm{ml})$ 에 비해 트레이 닝 8 주 $(18.1 \pm 3.99 \mathrm{pg} / \mathrm{ml})$ 와 트레이닝 종료 16주 $(18.1 \pm 4.19$ $\mathrm{pg} / \mathrm{ml}$ )에 약간 감소함을 나타냈지만 통계적으로 유의한 차이 는 나타나지 않았다.

혈중 IL-15는 트레이닝 전 $(125.3 \pm 11.6 \mathrm{pg} / \mathrm{ml})$ 에 비해 트 레이닝 8 주 $(234.4 \pm 39.7 \mathrm{pg} / \mathrm{ml})$ 와 트레이닝 종료 16 주 $(254.2 \pm$ $14.0 \mathrm{pg} / \mathrm{ml})$ 에 통계적으로 유의하게 $(p<0.05)$ 증가함을 나타
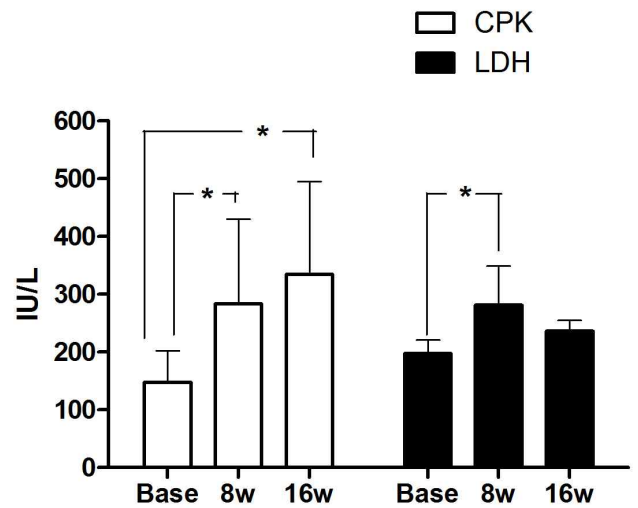

Fig. 2. The change of $\mathrm{CPK}$ and $\mathrm{LDH}$ during 16 weeks.

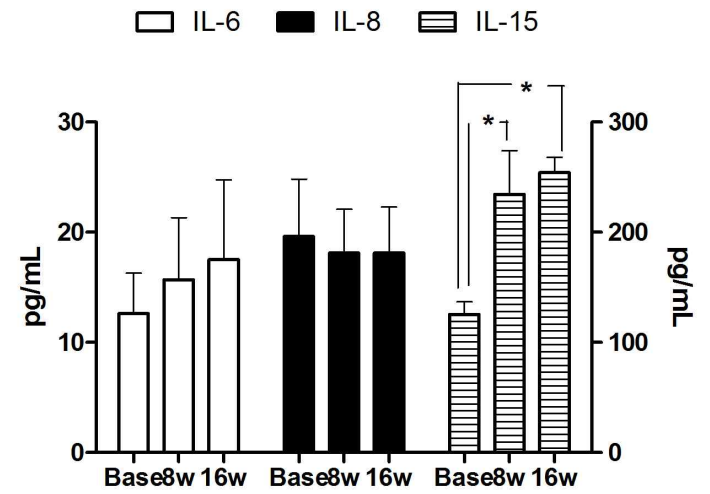

Fig. 4. The change of IL-6 and IL-8, IL-15 during 16 weeks. 
냈지만 트레이닝 8 주와 트레이닝 종료 16 주의 차이는 나타 나지 않았다.

\section{고 찰}

\section{6주 근력 트레이닝 후 신체적 특성}

현재 역도관련 대부분의 연구는 운동역학적인 면에 초점을 맞춰 진행되어 왔으며 국내연구로서는 중학교 역도 선수를 대상으로 대조군과 생리적 지표로서 등속성 근력을 포함한 체력 및 혈액분석 등을 비교한 연구[25]의 연구가 있지만 횡단 적(cross sectional) 연구로서 본 연구와 비교하여 분석 시에는 어려움이 있다.

본 연구에서의 신체적 특성 중, 체중, 체지방률은 유의하진 않았지만 약간 증가함을 나타냈고 이는 근력 또는 저항성 트 레이닝 형태가 체중의 증가를 유도하는 점을 볼 때, 타당한 결과라 사료된다. Maynar 등[12]은 스페인의 국가대표 남자 역도선수를 대상 $(\mathrm{n}=19)$ 으로 한 연구에서는 20 주간 $1-\mathrm{RM}$ 의 70 95\% 강도의 웨이트 트레이닝으로 체중은 약 $1.6 \mathrm{~kg}$, BMI는 약 $0.6 \mathrm{~kg} / \mathrm{m}^{2}$ 으로 유의하게 증가되어 본 연구의 결과와 유사 한 경향을 나타냈다. 하지만 본 연구에서 위의 선생연구와는 달리 체중이 유의한 증가를 나타내지 못한 이유는 본 연구의 트레이닝 기간이 위의 선행연구보다 4 주가 짧아서라기보다는 대상자가 중학생이며 이는 성인만큼 트레이닝 인한 근 비대 및 합성이 제지방 증가를 통한 체중 증가에 크게 영향을 미치 지 못한 결과라 사료된다.

\section{6주 근력 트레이닝 후 피로요인}

말초적 피로요소인 암모니아 $\left(\mathrm{NH}^{+}\right)$는 주로 근육에서 이루 어지고 운동량과 비례하며, 무기인산염 $(\mathrm{Pi})$ 은 생리적 피로유 발 요인 중 피로의 진전을 가장 잘 반영하고 있는 요인의 하나 로 장력 발생 시 칼슘에 대한 민감성을 감소시켜 피로의 요소 로 작용하는 생리적 특성을 나타낸다[16].

28 명의 엘리트 주니어 역도선수를 대상으로 2주 high volume resistance training을 실시한 후, 혈중 젖산과 암모니아 분석을 한 결과 운동전에 비해 운동후의 혈중 젖산과 암모니 아가 감소하였고 이는 고강도 트레이닝에 대한 적응이라 보고 [24]하였다.

본 연구에서 암모니아와 무기인산은 운동전( 0 주)에 비하여 운동중(8주)과 운동종료(16주) 모두 증가함을 나타냈지만 유 의한 차이는 나타나지 않았다. 이렇듯 혈중 암모니아와 무기 인산이 트레이닝이 지속됨으로 인해 유의하지 않았지만 조금 씩 증가하는 경향을 나타낸 것은 지속적인 16 주 근력 트레이 닝으로 인한 피로축척이 조금씩 진행되고 있는 상태이며 이러 한 결과는 일선 지도자 및 코치들에게 운동경험이 적은(1년 이하)중학교 역도 선수들을 지도할 경우, 피로 회복에 대한 중요성이 강조되어야 되는 부분이라 사료된다.

\section{6주 근력 트레이닝 후 근 손상}

$\mathrm{CK}$ 와 $\mathrm{LDH}$ 는 운동으로 유발된 근육 통증과 산화적 손상에 관련이 있으며[9], 고강도 운동자극에 의해 직접적인 세포막의 파괴 및 조직의 괴사, 스트레스에 의한 지질과산화 등에 의해 세포막의 투과성이 증가되면 세포질 내의 $\mathrm{LDH}$ 가 혈중으로 방출된다[8].

또한 저항성 운동을 동반한 강한 근 수축은 활동하는 근육 부위에 허혈 재 관류(ischemia-reperfusion)를 가져오며 활성 산소(free radical)는 골격근의 허혈 재관류 상해(ischemia-reperfusion injury)의 매개체(mediator)로 작용하여 결과적으로 $\mathrm{CK}$ 가 증가함을 나타낸다[10].

본 연구에서 $\mathrm{CK}$ 의 경우, 운동전(0주)에 비하여 운동중(8주) 과 운동종료 $(16$ 주)가 유의하게 $(p<0.05)$ 증가함을 나타내었고 운동중 $(8$ 주)에 비해 운동종료(16주) 시에도 약간 증가함을 나 타냈으나 유의한 차이는 나타내지 않았다. $\mathrm{LDH}$ 의 경우도 $\mathrm{CK}$ 와 같이 운동전( 0 주 $)$ 에 비하여 운동중 $(8$ 주)이 가장 유의하게 $(p \times 0.05)$ 높음을 나타냈지만 운동종료(16주) 시에는 다시 떨어 지는 경향을 나타냈다. 이렇듯 $\mathrm{LDH}$ 가 트레이닝 종료(16주) 시 다시 감소하는 결과는 고강도 운동에 따른 세포막 파괴와 조직의 괴사 등이 감소한 것이며 이는 트레이닝 효과가 반영 된 것으로 동일한 운동부하는 규칙적인 트레이닝으로 인해 더 낮은 강도로 받아들인 adaptation 현상[13]이라 사료된다.

\section{6주 근력 트레이닝 후 산화적 손상}

MDA (malondialdehyde)는 산화적 손상으로 인한 지질과 산화의 척도이며 강한 상 - 하체의 저항성 운동 후 높게 나타 난다.

plasma $\mathrm{MDA}$ 는 운동중 $\mathrm{CK}$ 활동과 상관이 있으며 고강도 저항성 훈련은 활성산소 형성 가져오고 이러한 활성산소는 생리적 스트레스로 야기되는 근육조직의 적응역할을 하게 된 다. 저항성 운동중 근육의 허혈 재관류와 운동 후 호중구로부 터 인체의 산화적 파열로 인한 활성산소는 신중하게 고려되어 야 한다[21]고 위험성을 제시하였다.

본 연구에서 $\mathrm{MDA}$ 는 트레이닝 전(0주)에 비하여 트레이닝 중 $(8$ 주)이 가장 유의하게 $(\beta \times 0.05)$ 높음을 나타냈고 운동종료 (16주) 시에는 운동 전(0주) 수준으로 회기 함을 나타냈다. 이 러한 현상은 트레이닝 8주가 고강도 저항성 부하로 인한 산화 적 손상이 가장 높은 시기임을 짐작할 수 있고 운동종료(16주) 시에 감소함은 트레이닝으로 인한 산화적 적응을 나타낸 것으 로 사료된다.

TAS (total antioxidant status)은 산화적 손상에 따른 항산 화 요인으로 광범위하게 사용되는 지표이다.

Caimie 등[3]은 대조군과 지구성 그룹(사이클과 지구성 수 영), 파워 그룹(스프린터 러닝과 수영, 역도선수), Mix 그룹(농 구, 유도, 수구)으로 나누어 운동 테스트 전, 후 지질과산화와 $\mathrm{TAS}$ 를 비교한 결과, 지질과산화 물질인 $\mathrm{TBARS}$ 와 항산화 물 
질인 TAS가 대조군을 제외한 파워그룹에서 가장 높음을 나타 냈다.

본 연구에서 TAS는 트레이닝 전(0주)에 비하여 트레이닝 중 $(8$ 주 $)$ 이 가장 유의하게 $(p<0.05)$ 높음을 나타냈고 운동종료 (16주) 시에는 운동전(0주) 수준으로 회기 함을 나타냈다. 이는 $\mathrm{MDA}$ 에서 경향과 일치하는 결과이며 트레이닝 중(8주)에 가 장 높은 $\mathrm{MDA}$ 레벨을 나타냈을 시 TAS 또한 가장 높이 발현되 었고 이는 운동에 의한 산화적 스트레스로 인해 TAS가 증가함 을 나타낸다[11]는 결과와 일치하며, 결국 트레이닝으로 높아 진 산화를 막기 위해 항산화 상태가 더불어 높아진 것이라 사료된다. 또한 전반적으로 이러한 요인들(피로물질과 근손상 물질, 산화적 손상)은 운동초기(8주)에 가장 높았고 트레이닝 후반기(16주)에는 전반적으로 감소하는 경향을 나타내 트레이 닝로 인한 적응을 나타낸 것으로 사료된다.

\section{6주 근력 트레이닝 후 myokine}

염증은 다양한 만성적 질환(chronic disease)과 관절염 (rheumatoid arthritis), 비만(obesity), 제 2형 당뇨(type 2 diabetes), 고혈압(hypertension), 심혈관질환(cardiovascular disease), 말초혈관질환(peripheral vascular disease), 골다공증 (osteoporosis), 암(cancer)과 관련이 있다[6]. 현재까지 IL-6 및 IL-8, IL-15는 염증성(inflammatory) maker로 널리 인식되어 왔다. 하지만 최근 운동하는 골격근에서의 cytokine의 발현은 혈액으로 방출되며 이러한 운동으로 유발된 cytokine은 "myokines"이라 이름 불리어 진다[18].

염증성 cytokine은 1990년대 중반까지 내장과 피하지방 조 직에서 cytokines (adipokines) 방출이 주요 근원으로 간주되 어 왔으나, 최근에는 지방조직(adipose tissue)으로부터 유발 된 IL-6는 몸 전체의 $10-35 \%$ 밖에 되지 않는 것으로 알려져 있다[7]. 이는 IL-6가 수축하는 근육에서의 더 많이 생성된다는 것을 간접적으로 입증하여 준다.

최신 연구들로 인해 근육에서 생성 및 방출되는 cytokines (myokines)은 골격근에서 지방조직을 사용하는 주요 분비 분 자이며[18], 오늘날 IL-6 및 IL-8, IL-15, Fibroblast growth factor 21, brain-derived neurophic factor (BDNF)는 myokines으 로 정의되고 있다[2].

이러한 Myokine은 골격근에서 분비 및 합성되고 다른 기관 에 영향을 미치며 근 성장 조절 또는 주변 분비 대사에 기여한 다[18,22].

IL-6는 일회성 운동시 안정시의 약 100 배 정도 증가되고 이 는 운동기간 및 강도, 동원된 근육량에 의해 기인[19] 하는 것 으로 볼 때, 본 연구에서 IL-6가 통계적으로 유의한 차이가 나진 않았지만 트레이닝 전(0주)과 트레이닝 중(8주), 트레이 닝 종료 시(16주)에 조금씩 증가함을 나타낸 결과는 일리가 있다고 사료된다. 또한 Carey등[4]은 증가된 IL-6가 GLUT4 (glucose transporter 4) 전위를 통해 인슐린-자극 글루코스 섭
취를 증가시키고 골격근과 지방조직에서 AMPK (AMP-activated protein kinase) 활성을 촉진시켜 골격근에서 지방산화 와 글루코스 섭취를 증감시킨다는 보고는 본 연구의 IL-6가 16 주 트레이닝이 지속됨으로 인해 시간이 지남에 따라 증가한 결과와 부합되는 내용이라 사료된다.

IL-8은 chemokine의 하나이며 CXC receptor 1 (CXCR1)과 관련이 있으며 인간의 미세혈관 내피세포(microvascular endothelial cell)에서 발현되며 혈관신생(angiogenesis)을 유발 한다[17].

본 연구에서 IL-8은 트레이닝 전(0주)에 비해 트레이닝 중(8 주), 트레이닝 종료(16주) 시까지 감소하는 경향을 나타내어 16 주 저항성 트레이닝은 혈관신생 관련에는 그리 많은 영향을 미치지 못한 것으로 사료된다.

Neilsen 등[15]은 IL-15는 골격근에서 발현되는 가장 풍부 한 cytokine의 하나이며 근육성장의 anabolic factor로 정의되 며 골격근에서 높은 발현은 결과적으로 조직의 비대 (hypertrophy)를 가져온다고 보고하였다. 또한 IL-15은 정기 적인 트레이닝으로 인해 근육에 축적되며 높은 레벨의 순환 IL-15은 체지방을 유의하게 감소시키며 골 무기질을 증가시킨 다[22].

한편 폐경 후, 고령 여성을 대상으로 16 주 저항성 트레이닝 을 실시한 선행연구[20]는 16주 전과 비교하여 트레이닝 후, 안정시 IL-15가 증가는 하였지만 유의한 차이는 나지 않았다 고 보고하였다.

본 연구에서 위의 선행연구와 비교시 여러 가지 차이 요 인은 있지만 가장 중요한 것은 IL-15가 16 주 규칙적인 저항 성 트레이닝으로 인해 트레이닝 전(0주)에 비해 트레이닝 중 (8주)과 트레이닝 종료(16주) 시까지 유의하게 $(p<0.05)$ 증가 시킨 점이다. 이러한 결과는 16 주 트레이닝이 근육합성 및 비대에 영향을 미쳤다고 사료되나 이것이 직접적인 영향을 미쳤다고는 단정 짓기 어렵다(본 연구에서 muscle mass나 lean body mass를 측정치 않았으므로)고 생각되며 추후 트 레이닝에 대한 IL-15의 다양한 연구가 필요하다 사료된다. 결 국 본 연구에서 측정한 myokine 중 IL-6는 트레이닝 중(8주) 와 트레이닝 종료(16주) 시에 증가는 경향을 나타냈지만 유 의한 차이는 나타내지 못했고 IL-8또한 통계적으로 유의한 차이를 나타내지 못했다. L-15만이 트레이닝 전(0주)에 비해 트레이닝 중(8주)와 트레이닝 종료(16주) 시에 유의한 차이를 나타내 myokine관련 다양한 운동강도와 기간에 따른 관련 연구가 필요 시 된다.

현재까지 IL-6 및 IL-8, L-15는 염증을 일으키는 특징을 가지 고 있으며 몇몇의 만성적인 질환에서 발병기전 역할을 하는 것으로 제안되고 있었으나 최근에는 골격근에서 IL-6 발현은 전신운동으로 인한 수축에 의해 증가되기 때문에 최근 이러한 IL-6와 IL-8은 염증성인자가 아니며 운동에 의한 긍정적 효과 를 유발하는데 중요한 역할을 하는 cytokine으로 나타났다 
[18]. 다만 이를 명확하게 증명하기 위해 근 biopsy를 통해 골 격근에서 분석하지 못한 것은 본 연구의 제한 점이며 최근에 지방조직(adipose tissue)으로부터 유발된 IL-6가 몸 전체의 $10 ~ 35 \%$ [9]을 가만해 볼 때, 나머지는 골격근(65 90\%)에서 발 현되는 것으로 보아 본 연구의 결과는 설득력이 있다고 사료 된다. 더욱이 본 연구의 대상자들이 의학적 질환이 없는 건강 한 중학교 엘리트 역도선수이기 때문에 16 주 동안 증가한 이 러한 cytokine은 염증성 인자(pro-inflammatory)로 해석되기 보단 근육이 수축함에 따른 대사적 물질인 myokine으로 해석 하는 것이 바람직하다고 사료된다.

\section{결 론}

본 연구의 목적은 중학교 엘리트 역도선수를 대상으로 16 주 근력운동과 TRX 및 코어 트레이닝을 실시하여 기초체력과 피 로, 근 손상, 산화적 손상, Myokine에 미치는 영향을 분석하여 다음과 같은 결론을 얻었다.

첫째, Ammonia와 Phosphate은 트레이닝 전(0주)에 비해 트레이닝 후(16주) 증가함을 나타냈지만 통계적으로 유의한 차이는 나타나지 않았다.

둘째, 근 손상 물질인 $\mathrm{CPK}$ 는 트레이닝 전(0주)에 비해 트레 이닝 8 주에 통계적으로 유의한(p<0.05) 증가를 나타냈으며 8 주와 16 주에는 유의한 차이는 나타내지 않았다. LDH는 트레 이닝 전 $(0$ 주)에 비해 트레이닝 8 주에 통계적으로 유의한 $(p<0.05)$ 증가를 나타냈지만 트레이닝 후(16주)에는 안정시 수 준으로 회기하는 경향을 나타냈다.

셋째, 산화적 손상 지표인 $\mathrm{MDA}$ 는 트레이닝 8 주가 트레이 닝 전과 16 주에 비해 통계적으로 유의한( $p<0.05)$ 증가를 나타 냈으며 항산화 지표인 TAS 또한 트레이닝 전에 비해 트레이닝 8 주에서 통계적으로 유의한( $p<0.05)$ 증가를 나타냈다.

넷째, Myokine인 IL-6와 IL-8은 트레이닝 전(8주)에 비해 트레이닝 후(16주) 증가함을 나타냈으나 유의한 차이는 나타 나지 않았고 IL-15는 트레이닝 전(0주)에 비하여 트레이닝 8주 와 16 주에 통계적으로 유의한 $(p \times 0.05)$ 증가를 나타냈다.

이상의 내용을 종합한 결과, 16 주 근력운동과 TRX 및 코어 트레이닝은 피로물질을 제외한 근 손상, 항산화 물질, Myokine에 긍정적 영향을 미친 것으로 나타났다.

\section{감사의 글}

본 논문은 영산대학교 교내연구비 지원에 의하여 연구 되었 음.

\section{References}

1. Ahn, J. C., S. H. Woo, H. J. Ahn, W. H. Chun, I. H. Cho, J. H. Cha, S. S. Jeon, and J. S. Lee. 2005. The effect of Abs
\& back training program on isokinetic muscular function in elite women weightlifter. J. Korean Phys. Edu. 19, 47-54.

2. Broholm, C. and B. K. Pedersen. 2010. Leukaemia inhibitory factor--an exercise-induced myokine. Exerc. Immunol. Rev. 16, 77-85.

3. Caimi, G., B. Canino, G. Amodeo, M. Montana, and R. Lo Presti. 2009. Lipid peroxidation and total antioxidant status in unprofessional athletes before and after a cardiopulmonary test. Clin. Hemorheol. Microcirc. 43, 235-241.

4. Carey, A. L., G. R. Steinberg, S. L. Macaulay, W. G. Thomas, A. G. Holmes, G. Ramm, O. Prelovsek, C. Hohnen-Behrens, M. J. Watt, D. E. James, B. E. Kemp, B. K. Pedersen, and M. A. Febbraio. 2006. Interleukin-6 increases insulin-stimulated glucose disposal in humans and glucose uptake and fatty acid oxidation in vitro via AMP-activated protein kinase. Diabetes 55, 2688-2697.

5. Chun, W. H. and I. H. Cho. 2007. The effect of creatine supplementation on power output in elite weight lifters. $J$. Korean Spo. Resea. 18, 109-116.

6. Colbert, L. H., M. Visser, E. M. Simonsick, R. P. Tracy, A. B. Newman, S. B. Kritchevsky, M. Pahor, D. R. Taaffe, J. Brach, S. Rubin, and T. B. Harris. 2004. Physical activity, exercise, and inflammatory markers in older adults: findings from the Health, Aging and Body Composition Study. J. Am Geriatr Soc. 52, 1098-104.

7. Febbraio, M. A. and B. K. Pedersen. 2002 Muscle-derived interleukin-6:mechanisms activation and possible biological roles. FASEB. J. 16, 1335-1347.

8. Jennifer, M. S. and B. B. Jeffrey. 2001. Role of vitamin E and oxidative stress in exercise. Nutrition 17, 809-814.

9. Kanter, M. A., G. R. Lesmes, L. A. Kaminsky, J. La Ham-Saeger, and N. D. Nequin. 1998. Serum creatine kinase and lactate dehydrogenase changes following an eighty kilometer race. realationship to lipid peroxidation. Eur. J. Appl. Physiol. Occup. Physiol. 57, 60-63.

10. Liu, J. F., W. Y. Chang, K. H. Chan, W. Y. Tsai, C. L. Lin, and M. C. Hsu. 2005. Blood lipid peroxides and muscle damage increased following intensive resistance training of female weightlifters. Ann. N.Y. Acad Sci. 1042, 255-261.

11. Magalhães, J., R. Ferreira, F. Marques, E. Olivera, J. Soares, and A. Ascensão. 2007. Indoor climbing elicits plasma oxidative stress. Med Sci. Sports Exerc. 39, 955-963.

12. Maynar, M., R. Timon, A. González, G. Olcina, F. Toribio, J. I. Maynar, and M. J. Caballero. 2010. SHBG, plasma, and urinary androgens in weight lifters after a strength training. J. Physiol. Biochem 66, 137-142.

13. Messonnier, L., C. Denis, F. Prieur, and J. R. Lacour. 2005. Are the effects of training on fat metabolism involved in the improvement of performance during high-intensity exercise? Eur. J. Appl. Physiol. 94, 434-441.

14. Moon, Y. J. 2009. Weightlifting, strength training techniques step-by-step instructions. pp. 87-92, 1th ed., Korea Institute of Sport Science, Seoul.

15. Nielsen, A. R., R. Mounier, P. Plomgaard, O. H. Mortensen, M. Penkowa, T. Speerschneider, H. Pilegaard, and B. K. Pedersen. 2007. Expression of interleukin-15 in human skel- 
etal muscle effect of exercise and muscle fiber type composition. J. Physiol. 584, 305-312.

16. Pack, I. Y. 2002. Exercise physiology \& exercise prescription. pp. 179-191, 2th eds., Dehanmidia, Seoul.

17. Pedersen, B. K. and C. P. Fischer. 2007. Beneficial health effects of exercise-the role of IL-6 as a myokine. Trends. Pharmacol. Sci. 28, 152-156.

18. Pedersen, B. K. and M. A. Febbraio. 2008. Muscle as an endocrine organ: focus on muscle-derived interleukin- 6 . Physiol. Rev. 88, 1379-1406.

19. Petersen, A. M. and B. K. Pedersen. 2005. The anti-inflammatory effect of exercise. J. Appl. Physiol. 98, 1154-1162.

20. Prestes, J., G. Shiguemoto, J. P. Botero, A. Frollini, R. Dias, R. Leite, G. Pereira, R. Magosso, V. Baldissera, C. Cavaglieri, and S. Perez. 2009. Effects of resistance training on resistin, leptin, cytokines, and muscle force in elderly post-menopausal women. J. Sports Sci. 27, 1607-1615.

21. Pyne, D. B. 1994. Regulation of neutrophil function during exercise. Sports Med 17, 245-258.

22. Quinn, L. S., B. G. Anderson, L. Strait-Bodey, A. M. Stroud, and J. M. Argilés. 2009. Oversecretion of interleukin-15 from skeletal muscle reduces adiposity. Am J. Physiol. Endocrinol. Metab. 296, E191-202.

23. Vincent, H. K. and K. R. Vincent. 1997. The effect of training status on the serum creatine kinase response, soreness and muscle function following resistance exercise. Int. J. Sports Med 18, 431-437.

24. Warren, B. J., M. H. Stone, J. T. Kearney, S. J. Fleck, R. L. Johnson, G. D. Wilson, and W. J. Kraemer. 1992. Performance measures, blood lactate and plasma ammonia as indicators of overwork in elite junior weightlifters. Int. J. Sports Med 13, 372-376.

25. Yoon, J. H., I. G. Jeong, and H. H. Lee. 2002. Analysis of isokinetic strength and muscle fatigue on knee joint in middle-school weight lifters. J. Korean Sports Med 20, 189-200.

초록 : 16 주 저항성 트레이닝이 엘리트 역도선수의 피로물질과 근 손상, 산화적 손상, myokine에 미치 는 영향

김철우 ${ }^{1}$ 김군도 ${ }^{2} \cdot$ 강성훈 $^{3} \cdot$ 박찬호 $^{4} \cdot$ 김귀백 $\cdot$ 김영일 ${ }^{1} \star$

( ${ }^{1}$ 영산대학교 스포츠건강관리학과, ${ }^{2}$ 부경대학교 미생물학과, ${ }^{3}$ 동아대학교 체육학과, ${ }^{4}$ 부산대학교 체육학과)

본 연구의 목적은 16 주 근력 트레이닝을 동반한 TRX, 코어 훈련이 엘리트 역도 선수의 피로물질과 근 손상, 산화적 손상, myokine에 미치는 영향을 규명하기 위함이다. 본 연구 대상자들은 총 10 명(남 6 명, 여 4명)으로 구성되어 있으며 16 주 근력 운동과 더불어 코어 및 TRX 트레이닝을 실시하여 다음과 같은 결과를 얻었다.

Ammonia와 Pi는 트레이닝 전에 비해 점차적으로 증가함을 나타냈으나 통계적으로 유의한 차이는 나타나지 않았다. 근 손상 물질인 $\mathrm{CK}$ 는 트레이닝 전에 비해 8 주에 유의한 $(p<0.05)$ 증가를 나타냈으며, $\mathrm{LDH}$ 는 트레이닝 전에 비해 8 주에 유의한 $(p<0.05)$ 증가를 나타냈지만 16 주에는 감소하는 경향을 나타냈다. 산화적 손상 지표인 MDA는 트레이닝전과 16 주에 비해 트레이닝 8 주에서 유의한( $p \times 0.05)$ 증가를 나타냈으며, 항산화 지표인 TAS 또한 트레이닝 전에 비해 트레이닝 8 주에서 통계적으로 유의한( $p \times 0.05)$ 증가를 나타냈다. Myokine인 IL-15는 트레이닝 전에 비하여 트레이닝 8주와 16 주에 통계적으로 유의한(p<0.05) 증가를 나타냈다.

결과적으로 16 주 고강도 근력 트레이닝은 엘리트 중학교 역도선수의 피로물질과 근 손상, 산화적 손상, myokine에는 긍정적이 영향을 미친 것으로 나타났다. 